\title{
Age of European silver eels during a period of declining abundance in Norway
}

\author{
Caroline Durif ${ }^{1}$, Ola Diserud ${ }^{2}$, Odd Terje Sandlund ${ }^{3}$, Eva Thorstad $^{2}$, Russel Poole ${ }^{4}$, Knut \\ Bergesen $^{2}$, Rosa Escobar-Lux ${ }^{1}$, Steven Shema ${ }^{5}$, and Leif Asbjørn Vøllestad ${ }^{6}$ \\ ${ }^{1}$ Institute of Marine Research \\ ${ }^{2}$ Norwegian Institute for Nature Research \\ ${ }^{3}$ Norwegian Institute for Nature Research (NINA) \\ ${ }^{4}$ Marine Institute \\ ${ }^{5}$ Grótti ehf. \\ ${ }^{6}$ University of Oslo
}

May 5, 2020

\begin{abstract}
The European eel (Anguilla anguilla) is critically endangered throughout its distribution range. Knowledge about age distribution of future spawners (silver eels) is essential to monitor the status and contribute to the recovery of this species. Determination of age in anguillid eels is challenging, especially in eels from the northern part of the distribution area where growth is slow and age at maturation can be up to 30 years or more. Eels from the river Imsa in Norway have been monitored since 1975 and this reference time-series has been used to assess the stock at the European level. Population dynamics in this catchment were analyzed during the late 1980s by estimating ages on whole cleared otoliths. However, techniques for revealing annual increments on otoliths have evolved over the years sometimes yielding significant differences in age estimates. In this study, the historical otolith data were reanalyzed using a grinding and polishing method rather than reading the whole otolith. The new age estimates were considerably higher than the previous ones, sometimes by up to 29 years. Since the 1980s, mean age of silver eels only slightly increased (from 19 to 21 years in the 2010s). This was mainly due to the disappearance of younger silver eels (less than 15 years) in the 2010s. The new age estimates agreed with the steep decline in recruitment which occurred in the late 1980s in the Imsa catchment. Growth (30 mm y-1) has not changed since the 1980s, although density in the catchment has decreased. Revealing and reading age of slow growing eels remain a challenge but adding a measure of otolith reading uncertainty may improve age data collection and contribute to recovery measures for this species.
\end{abstract}

\section{Keywords}

Anguilla anguilla, ageing method, catchment, endangered species, growth, migration, otolith, river, sex ratio

\section{Introduction}

Despite their remarkable ability to adapt to all kinds of environments, the European eel, Anguilla anguilla, population has been in decline, at least since the 1960s (ICES, 2019; Dekker \& Beaulaton, 2016). Recruitment to freshwater habitats decreased by more than $90 \%$ in the early 1980s and since 2008 the European eel has been listed as Critically Endangered on the International Union for Conservation of Nature (IUCN) red list 
(Jacoby \& Gollock, 2014). Causes of the decline are related to habitat loss, overfishing, climate change, pollution, parasites and diseases (Aschonitis et al., 2017; Drouineau et al., 2018).

The European eel is semelparous and panmictic (Als et al., 2011). It spawns in the Sargasso Sea, but is distributed across Europe, from northern Norway to northern Africa and far into the Mediterranean (Schmidt \& Regan, 1923; Dekker, 2003a). Larvae drifting with the Gulf Stream metamorphose into glass eels when they reach the continental shelf. These glass eels colonize coastal and freshwater habitats where they spend their growth phase until they start to mature into silver eels which will migrate back to the Sargasso Sea for spawning (Bertin, 1956; Tesch, 2003).

The status of the stock is primarily assessed through time series of recruiting glass eels (or elvers) to freshwater at different monitoring stations across Europe (ICES, 2000). A severe reduction in glass eel recruitment, more marked in the northern part of the distribution area, became apparent in the early 1980s (Moriarty, 1986,1990; Dekker, 2003b, 2004; ICES, 2016; Bornarel et al., 2017). However, signs of decrease in the standing stock (yellow stage) date from the 1960s (Aalto et al., 2016; Dekker, 2003c).

At some of the monitoring stations, like in the river Imsa, Norway, both upstream ascending elvers and downstream migrating silver eels are trapped and counted (Sandlund et al., 2017). The Imsa reference timeseries was started in the 1970s, and the age distribution and the population dynamics in this catchment were especially studied in the 1980s and 1990s, yielding fundamental knowledge on the ecology of European eels (Vøllestad et al., 1986; Vøllestad \& Jonsson, 1986, 1988; Vøllestad, Jonsson, Hvidsten, \& Næsje, 1994). Following the awareness of the European eel population crash, countries across Europe developed management plans in accordance with a European Union Regulation (EC 1100/2007). Although a non-EU country, Norway followed in 2010, with a ban on eel fishing and the Imsa time-series became even more relevant to monitor the local sub-stock (Poole et al. 2018).

Knowledge on age structure is essential to assess the status of a population. Determination of age in fish is challenging, especially in long-lived species such as the European eel. For this species, otoliths (or earstones) are prepared so that annual rings (annuli), marking periods of fast and slow growth, become visible and can be counted to give an age estimate (Moriarty, 1973, 1983, Svedäng, Wickström, Reizenstein, Holmgren, \& Florenius, 1998). Four main methods have been used for preparing otoliths: 1) Grinding and polishing, 2) slicing, 3) burning and cracking, and 4) clearing of whole otoliths in ethanol (in toto method). It has been debated what is the better method (Vøllestad \& Næsje, 1988; ICES, 2009). Different methods yield different estimates (Moriarty \& Steinmetz 1979). The suitability of each method depends on the age and growth of individuals (Vøllestad, Lecomte-Finiger, \& Steinmetz, 1988). For example, burning and cracking is more suitable for slow-growing eels, because of the shape of their otolith and the numerous but short growth increments (Vøllestad \& Næsje, 1988). The "in toto" method (clearing whole otoliths) is fast and inexpensive, but best suited for young eels (Vøllestad and Næsje, 1988). During recent years, a manual regarding the best practice for ageing eels has been developed (ICES, 2009, 2011). However, methods are still debated due to a general lack of validation and of different growth patterns in such a widespread species.

Once annuli are revealed, interpretation remains challenging. For example, traumatic events, such as high temperatures in the summer, diseases, or stress can cause supernumerary check or "false" checks (Domingos, Costa, \& Costa, 2006; Graynoth, 1999; ICES, 2009; Tzeng, Wu, \& Wickström, 1994; Svedäng et al., 1998). In addition, observations can vary between readers, over time and between laboratories.

Age estimates have been validated in some cases using chemical marking of otoliths (Chrisnall \& Kalish 1993; Dekker, 1986; Oliveira, 1996; Svedäng et al., 1998), external color marking (Chisnall \& Kalish 1993; Poole \& Reynolds 1996) or indirect methods using individual mark-recapture techniques (Poole \& Reynolds 1996; Beentjes \& Jellyman, 2015), or by introducing eels in a pristine waterbody (Vøllestad \& Næsje 1988; Wickström, Westin, Clevestam, 1996; ICES, 2009). However, validations for the European eel have been done mostly on young individuals with a maximum age of 14 years and unfortunately, there are still too few examples of validation of ageing methods in eels.

In the earlier years (1980-90s), the age of silver eels from the river Imsa was determined using the in 
toto method (IT), and it was later suspected that these ages were underestimated. Since the otoliths had been maintained, it was decided to reanalyze them using the consensus method: grinding and polishing method (GP) and to compare both age estimates. Additionally, new otolith samples were collected in the 2010s and treated in the same way (GP method) to investigate possible changes in their age distribution of silver eels since the decline of the population (Poole et al., 2018). Finally, using this new dataset, the possible relationship between the number of ascending recruits and the number of descending silver eels was examined to reanalyze previous models (Vøllestad \& Jonsson 1988) established for the Imsa eel stock during the period 1975-1987.

\section{Material and Methods}

\section{Study location}

The river Imsa in southwestern Norway (Figure 1) is an unregulated oligotrophic system. The catchment covers an area of 12800 ha, of which 1536 ha $(12 \%)$ is lake surface (major lakes are Imsvatnet, 40 ha, and Storavatnet, 819 ha). A trap catching descending silver eels as well as ascending juveniles is located about 100 $\mathrm{m}$ from the river outlet in the sea. The distance from the trap, which has been in operation since 1975, to the upper end of eel habitat in the catchment is set at $20 \mathrm{~km}$, and the eels ascend the system up to an altitude of approximately $215 \mathrm{~m}$ above sea level (Vøllestad \& Jonsson 1988). Descending, predominantly silver, eels are caught in a Wolf trap (apertures $10 \mathrm{~mm}$, inclination 1:10). The juveniles entering this watershed are small yellow eels (elvers or recruits) that are typically 70-90 $\mathrm{mm}$ long and weighing less than 1.0 gram, although a few individuals may be larger. The distance from the nearest lake along the free-flowing river to the fish trap is $970 \mathrm{~m}$. There has been no stocking of eels in this watershed. Before 2006, there was a restricted seasonal yellow and silver eel fishery upstream of the trapping station. The number of ascending recruits and descending silver eels is given per calendar year.

Wolf traps with aperture $10 \mathrm{~mm}$ generally catch all eels larger than approximately $25 \mathrm{~cm}$ in length, which includes all silver eels in the river Imsa (Vøllestad \& Jonsson, 1986). The elver trap leads all ascending recruits into a capture chamber where their numbers are recorded, and sub-sampling of size is performed, before they are released to continue upstream. The traps are checked twice every day (at circa 08:00 and 15:00 h).

\section{Otolith data and age determination}

Otoliths from the historical collection (collected in the 1980s and 90s) were initially read in toto by clearing them in $96 \%$ ethanol for 18-24 h before counting the annuli directly using a stereo microscope and $96 \%$ ethanol as refraction medium (Vøllestad, 1985). These otoliths were, since then, stored dry in an envelope, each labeled with length, sex and stage (yellow or silver). For the reanalysis, a subsample was selected from years with the highest sampling effort (1982, 1986, 1991 and 1992).

The more recent otoliths (from the 2010s) were sampled from eels caught during their downstream run in the river Imsa. Twenty-five silver eels were sacrificed per year (61 eels in 2016). Length, weight, fin and eye diameters were measured for stage determination (Durif, Dufour, \& Elie, 2005; Durif, Guibert, \& Elie 2009). The eels were dissected for sex determination and removal of otoliths. Otoliths from the 2010s were not analyzed using the old in toto method.

A total of 798 fish were processed. All otoliths (historical and new) were prepared by grinding, etching and staining and read according to the protocol described in ICES $(2009,2011)$ (Figure 2). The year 0 band was assigned as the first winter after the oceanic migration, i.e . it marked the beginning of the continental life stage. The last year was defined as the outer edge of the otolith since eels were caught during the fall season. Some otoliths had clear and regularly spaced annuli (Figure 2A). Others presented numerous tight rings, unevenly spaced, which sometimes joined in a "bundle" or fused into one large annulus on the other side 
of the otolith (Figure 2B, 2C). Whether these bundles represent one or several years is unknown. Here, we assumed that some of the marks forming a bundle represented false checks and thus one bundle represented one year. Otoliths were read by 2 or 3 observers, or for some samples by the same observer twice, but the second time several months after the first reading. As expected, some otoliths were easier to interpret than others, and the age estimates did not always agree between observers. To characterize the uncertainty in the readings, we assigned each age estimate with an Otolith Uncertainty Index (OUI) corresponding to how much the observations differed between observers/observations:

- OUI level 1: differences less than 3 years

- OUI level 2: differences between 3 to 5 years

- OUI level 3: differences of more than 5 years.

\section{Calculations and statistics}

Indicative growth rate of each individual was calculated by dividing the body length LT (mm) of the eel minus $70 \mathrm{~mm}$, which is the mean size of glass eels when they recruit to European coasts (Elie, 1979; Svedäng et al., 1996), by the continental age.

Differences in mean age and mean length between decades and between OUI levels were tested using linear regression models. Differences in proportion of OUI levels between decades were tested using a Chi-square test. Differences between length-weight relationships were tested with ANCOVA after the variables were log-transformed to investigate changes in condition over the decades. Statistics were carried out using the statistical software R (R Core Team, 2019, v. 3.6.0).

\section{Results}

\section{Age estimates}

Otoliths from 41 eels (5\%) were unreadable and were excluded from the analyses and the following percentages (Table 1). Most otoliths were assigned an OUI (Otolith Uncertainty Index) level 2, indicating a 4 to 5 years uncertainty $(47 \%)$. OUI level 1 otoliths (1 to 3 -year uncertainty) represented $14 \%$, and OUI level 3 (over 5-year uncertainty) represented $39 \%$ of the otoliths analysed. Age varied with OUI $\left(\mathrm{R}^{2}=0.04, \mathrm{~F}(2\right.$, $753)=17.8, \mathrm{p}<0.0001)$ : uncertainty increased with age. Length did not vary between OUI levels $\left(\mathrm{R}^{2}=0.006\right.$, $\mathrm{F}(2,750)=2.2, \mathrm{p}=0.11)$. The proportion of OUI level 3 otoliths was different across decades $\left(\mathrm{X}^{2}=45.729\right.$, $\mathrm{df}=4 ; \mathrm{p}<0.0001): 51 \%$ in the $1980 \mathrm{~s}, 28 \%$ in the $1990 \mathrm{~s}$ and $34 \%$ in the $2010 \mathrm{~s}$.

Estimated ages from the IT method were always lower than from the GP method (Figure 3). Differences varied between 0 and $29 \mathrm{y}$ with a mean and a median equal to $11 \mathrm{y}$. The correlation between age estimates was significant $\left(\mathrm{R}^{2}=0.05, \mathrm{~F}(1,586)=30.8, \mathrm{p}<0.0001\right)$, but still too low to infer one estimate from the other (Figure 3 ). The new and old age distributions were different from each other (Figure 4).

\section{Comparison of new age estimates and length at silvering over the years}

Out of the 798 eels, 751 were females, 43 males, and 4 undifferentiated. Ninety-three percent were at the silver stage, the remaining were either yellow or intermediate.

Mean age at silvering (all years) was $19 \mathrm{y}$ for females and 15 y for males (Table 1). During the last decade (2010s), mean age of females significantly increased compared to the 1980s and 90s (Table 1). This is due to the disappearance of young silver eels $(<15 \mathrm{y})$ during the 2010s (Figure 5). This corresponds to the lowest recruitment level which was reached in the 2000s (Figure 6), thus 12 to 15 years before the 2010s sampling.

Mean body length increased significantly from the 1980s to the 2010s (Table 1, Figure 7). Female length increased by $8 \mathrm{~cm}$ over the 30-year period (Table 1). When male silver eels were still caught in the trap, 
these migrated at a length of around $40 \mathrm{~cm}$. In the 2010s, male eels disappeared, as did the contingent of smaller female silver eels (around $50 \mathrm{~cm}$ ). We found no differences in length-weight relationship between decades $(\mathrm{F}(2,241)=1.37, \mathrm{p}=0.26)$.

\section{Growth}

Growth estimated based on the GP method were highly variable, and age of female eels was only slightly related to their body length $\left(\mathrm{R}^{2}=0.08\right)$. Mean growth calculated over the entire freshwater stage of the eels by using the new age estimates (GP method) was $30 \mathrm{~mm} \mathrm{y}^{-1}$ in females (min-max: $16-64 \mathrm{~mm} \mathrm{y}^{-1}$ ) and 24 $\mathrm{mm} \mathrm{y}^{-1}$ in males (min-max: $15-37 \mathrm{~mm} \mathrm{y}^{-1}$ ). Growth calculated with the old estimates (IT method) was 77 $\mathrm{mm} \mathrm{y}^{-1}$ for females and $72 \mathrm{~mm} \mathrm{y}^{-1}$ for males.

\section{Linking annual numbers of recruits and silver eels}

Both the number of ascending recruits (elvers) and descending silver eels have changed substantially during the period from 1975 to 2017 (Figure 3). The number of ascending recruits demonstrated large annual variation during the period 1975-1990, with a minimum of 2400 and a maximum of 46200 eels, and a mean number of 19000 ( \pm SD 15 200). From 1991 to 2017, the annual numbers of ascending recruits declined to a much lower level, varying between 5 and 8878 eels, with a mean of 2555 ( \pm SD 2512 ). The number of descending silver eels changed abruptly in 1988, from a mean of 5854 ( \pm SD 1180 ) eels during 1975-1988, to 2183 ( \pm SD 785) during 1989-2017.

The age distribution of the female silver eels migrating to the sea each year included up to 31 age classes (from 8 years to 39 years old). Thus, each year's silver eel run represented more than 20 age classes of recruits. We attempted to fit a Recruit-Stock analysis model by assigning descending silver eels to recruit cohorts according to mean decadal age distributions but found no significant relationship.

\section{Discussion}

Although widely geographically spread out, all European eels spawn in the Sargasso Sea and form one panmictic population. Some of their biological characteristics, such as age at maturation, growth, fecundity, can vary greatly depending on where they spend their growth phase, the yellow stage. It is unknown whether eels from certain regions contribute more to the spawning stock and whether this may change from year to year. The success of Anguilla anguilla as a species is probably linked to its incredible plasticity in terms of life-history strategies and biological characteristics. In the context of the decline, it is essential that all components of the population contribute to the spawning stock. The decline in recruitment has been more pronounced in the North than in the rest of Europe (1.9\% versus $8.9 \%$ of the references levels in 1960-1979, ICES 2019). Norway represents the limit of the distribution area and it is there that changes in densities are more likely be detected. The time-series from the river Imsa is important for monitoring the stock. The Norwegian red list assessment for eel has also been based on this time-series. The previous assessment has used a mean age at maturation of 8 years based on the previous studies (Vøllestad \&Jonsson, 1986, 1988). The present study reporting a mean age of 19 years for female silver eels will likely have an impact on the next revision of the Norwegian red listing (currently assessed as Vulnerable, VU).

\section{Otolith processing methods and reading uncertainty}

As expected, there were large differences in age estimates of eels between the two different methods, in toto (IT) and grinding and polishing (GP). The age difference was $11 \mathrm{y}$ on average with a maximum of $29 \mathrm{y}$. The differences were not systematic, but ages using GP were always older than using IT. The present study confirms that GP is a better method for estimating age in the European eel than clearing of whole otoliths in ethanol. Cracking and burning was previously tested on otoliths of Imsa eels, but the burnt otoliths were 
difficult to read (Vøllestad \& Jonsson, 1988). Revealing annuli on the otoliths is not the only challenge related to age estimation in eels. A proper validation of age determination is still lacking, especially for older eels (over 20 years) from northern latitudes, where growth is slow. In other words, it is uncertain whether all the annuli represent winter marks, since some can be very tightly distributed, forming bundles of annuli. In the present study, it was considered unlikely that all these bundled marks represented an annual increment; rather, one year was assigned to each bundle. In the absence of definitive annulus identification this was the best approach. It may have led to some under-estimation, but this was to some degree accounted for in the Otolith Uncertainty Index (OUI).

Further, in our study, $5 \%$ of the otoliths were unreadable. In comparison, this proportion was 10-30\% for eels caught in Mediterranean lagoons where eels frequently change salinity and habitat (Panfilli and Ximenes, 1994). Still, $39 \%$ of the otoliths from the Imsa were difficult to read (OUI, level 3: uncertainty $>5$ years). These may have qualified as "unreadable" by Panfilli and Ximenes (1994), but here we chose to assign a high uncertainty rather than discarding them.

Using otoliths of known age, Svedäng et al. (1998) showed that younger eels were consistently over-aged while older eels were under-aged. The reason for overestimations was the presence of supernumerary zones in younger eels that were misidentified as annuli. For older eels, it is difficult to detect annuli in the outer slow-growing part of the otolith. An additional inconsistency was found in readings by the same reader over time which could vary up to 6 years (Svedäng et al., 1998). The unknown age of glass eels at metamorphosis may add one to two years of uncertainty to the total age. Similarly, the outer bands may not be fully revealed at the edge of the otolith by a polishing and grinding method causing an under-ageing.

Some otoliths, however, are very clear and can be easily interpreted. Therefore, it is important to include some measure of confidence around the age determination, at least, until there is a proper age validation method. We suggest a simple method by implementing an otolith uncertainty index (OUI) such as described in the present study. Depending on the type of output where age data is needed, ranging from population dynamics models to management advice, subsets of data can be selected based on their OUI. The development of machine learning methods for automatic otolith image analyses is promising (Moen et al., 2018). An OUI index will also be useful in that sense, for selecting suitable learning datasets.

\section{Evolution of the age distribution of silver eels in the river Imsa}

As expected, age at silvering varied greatly in the eels from the river Imsa (females: 8-35 years; males: 9-23 years), but the overall mean varied only slightly across decades (from 19 to 21 years in the 2010s). Since most age readings had an associated uncertainty of 3 to 4 years, this 3 -year increase is meaningless, although statistically significant. Actually, given the disappearance of young silver eels (less than $15 \mathrm{y}$ ) during the more recent decades, it is surprising that the mean and median age were not more affected. However, mean age of silver eels is bound to increase even more in the river Imsa with the consistently low numbers of ascending recruits the last 2-3 decades. But in 2009 and 2014, elver recruitment increased and almost reached the 10 000-individual threshold. An effect on the number of silver eels might not be detected before at least 10-15 years later. If these two peaks do affect the number of silver eels, it will not happen before 2022. In any case, if recruitment does not improve, this increase will be short-lived, and perhaps non-detectable due to the low levels during most of the last 15 years.

\section{Length at silvering}

Eels are present in many types of habitats and salinities: coastal, lagoons, lakes, rivers, marshes, fjords, and estuaries. Length (and not only age) distributions can vary greatly among these habitats (Vøllestad 1992; Vøllestad \& Jonsson 1986; Svedäng, Neuman, \& Wickström, 1996; Holmgren, Wickström, \& Clevestam, 1997; Melia et al., 2006; Durif et al., 2009; Poole et al. 2018). All eels need to accumulate fuel for the sustained high-intensity swimming necessary for the journey to the Sargasso Sea, but females will face higher energetic demands in order to produce eggs. This leads to different life-history strategies and a sexual dimorphism 
based on differences in length at maturity (Bertin, 1956; Tesch, 2003). Male eels migrate at around $35 \mathrm{~cm}$ (in this study $40 \mathrm{~cm}$ ), minimizing the duration of their yellow stage, while females migrate at sizes of 40 to $130 \mathrm{~cm}$, optimizing their size to reach a higher fecundity (Helfman, Facey, \& Hales, 1987; Vøllestad, 1992; Tesch, 2003; Durif et al., 2009). In the northern part of the distribution area, eels (males and females) are on average larger than in southern areas, and this has been linked to the increasing distance they have to swim to reach the spawning area (Tesch, 2003; Durif et al, 2009; Vøllestad, 1992). Yet in the present study, which was located at a relatively high latitude $(58.90 \mathrm{~N})$, most female eels migrated at a body length around $60 \mathrm{~cm}$ and a small contingent of eels migrated at body length around 40-55 cm. Possibly, some eels could have stopovers on their way to the Sargasso Sea; but in the case of Norway, there is no obvious location for a stopover, since silver eel spawners take the northern route (north of the Shetlands) rather than through the Dover straight (Kettle, Vøllestad, \& Wibig, 2011; Westerberg, Sjöberg, Lagenfelt, Aarestrup, \& Righton, 2014). The best gonad-to-body size ratio under experimental artificial maturation, was found in eels longer than $70 \mathrm{~cm}$ (Durif, Dufour, \& Elie, 2006). Once a specific size is reached, a period of high growth probably triggers silvering (Huang et al., 1998; Durif et al., 2005). Recent work in reproductive endocrinology has identified the kisspeptin system as essential for the onset of puberty in mammals but also in teleost fish (Seminara et al., 2003; Zohar et al., 2010; Pasquier et al., 2018). In eels, kisspeptins regulate the expression of gonadotropins. They may be the link between environmental factors and the reproductive axis through the regulation of growth hormone (Huang et al, 1998; Zohar et al., 2010; Kim, Choi, Park, \& Choi, 2015).

\section{Growth of eels}

The new age estimates using the grinding and polishing (GP) method indicate that eels in the river Imsa spend a substantially longer period as yellow eels in freshwater than previously thought (Vøllestad \& Jonsson, 1986). Previous estimates of silver eels in the river Imsa, suggested a mean age of 5 years for male and 8 years for female silver eels (Vøllestad et al., 1986), while the new estimates indicated a mean age of 15 years for males and 19 years for females. At the time it was concluded that eels in the river Imsa grew quickly, with a mean size increment of around $70 \mathrm{~mm} \mathrm{y}^{-1}$, which is comparable to growth in brackish water and in southern Europe (Rossi \& Colombo 1976; Vøllestad, 1985; Acou et al., 2003). In the river Imsa, slower growth is more likely (this study: $30 \mathrm{~mm} \mathrm{y}^{-1}$, because at these latitudes the growth season is shorter than in southern Europe as eels stop feeding when the water is colder than 8-10 (Vollestad et al., 1986; Riley, Walker, Bendall, \& Ives, 2011; Westerberg \& Sjoberg, 2015). This was also visible through the patterns of the annuli. Tight, numerous rings are interpreted as short growth seasons. Our method to determine growth rate was simple and did not take into account changing growth rates over the lifetime. The new mean growth estimate in the river Imsa is $30 \mathrm{~mm} \mathrm{y}^{-1}$, which is less than half of what was previously documented. This new value is in line with newer growth estimates of eels in freshwater and in the northern part of the distribution range (Aprahamian 2000; Arai, Kotake, \& McCarthy, 2006; Lin, Lozys, Shiao, Iizuka, \& Tzeng, 2007; Simon, 2007, 2015; Silm, Bernotas, Haldna, Jarvalt, \& Noges, 2017).

Growth of eels in the river Imsa has not changed since the 1980s. This was contrary to what was expected. Water temperature has also increased due to climate change and this has provided longer growth seasons. Additionally, a reduced number of ascending recruits has led to a lower density of yellow eels in the freshwater habitat; this should have resulted in better growth and faster onset of the silvering process, leading up to silver eel descending at a younger age in recent years than in previous periods. Early analyses based on different ageing methodology did indicate density-dependent mortality in Imsa (Vollestad \& Jonsson, 1988), opening the possibility also for density-dependent growth.

There were very few individuals younger than 15 years in the samples from 2012-2016. This agrees with the large reduction in recruitment from the late1990s. The recruitment has remained low since then, with almost no recruitment in several years in the mid-2000s and later (Figure 6). This gives us extra confidence in the new age estimations. Silver eels younger than 15 years from 2012-2016 have entered the river after 1997-2001, hence with the large decline in recruitment a large decline in this age group was also expected. The IT method would have estimated most eels sampled in the 2010s to be around 10 years old with a cutoff 
value at 5 years, meaning a decline around 2007-2011. This was not the case and therefore estimates from the GP method are more likely.

\section{Sex ratio}

Male eels have always been scarce in the river Imsa; in the 1980s they represented 3-7\% of the total run, but they all disappeared in the 2010s (Poole et al, 2018). Sex determination in eels is metagamic, meaning it is non-genetic (Geffroy \& Bardonnet, 2016). Sex ratios are indeed skewed at individual localities and there is a geographic bias associated with latitude and longitude (Helfman et al. 1987; Oliveira, McCleave, \& Wippelhauser, 2001; Davey \& Jellyman, 2005). The general pattern is that male eels are more abundant at southern latitudes and mainly in the lower reaches of rivers, whereas females dominate at higher latitudes and with increasing distance to the sea. Additionally, high eel densities are usually associated with higher proportions of males (Parsons, Vickers, \& Warden, 1977; Beentjes \& Jellyman, 2003, 2015; Davey \& Jellyman 2005; Laffaille, Acou, Guillouet, Mounaix, \& Legault, 2006; Harrison, Walker, Pinder, Briand, \& Aprahamian, 2014); although, a study done in a laboratory showed opposite results (Huertas \& Cerda, 2006). This later study, and others, also suggest that sex determination occurs during the first 3 months of growth (Davey \& Jellyman, 2005; Huertas \& Cerda, 2006).

The density factor may affect sex ratio through 1) food availability, depletion of food resources and lower growth or 2) through social interactions: possibly through odors of conspecifics or even through cannibalistic behaviors which would skew the sex ratio since females are larger than males (Davey \& Jellyman, 2005).

Eel density in the Imsa catchment has severely decreased following the decline in recruitment since the late 2000s (Figure 6). However, in our study, growth has remained unchanged over the decades, and therefore cannot explain the disappearance of male eels. Therefore, social interactions (i.e.: density-dependence) are probably important for determining sex in eels.

\section{Link between ascending recruits and descending silver eels}

In the light of the low annual number of ascending juvenile eels and the relatively high number of silver eels, a mean age of silver eels at 19 years for females and 15 years for males indicates that mean annual mortality in freshwater has to be very low $(<<10 \%)$. The termination of eel fishing in the Imsa water course in 2006 has likely contributed to a reduced freshwater mortality, but natural mortality may anyway appear to have been very low all through the study period. In a river-lake system mainly inhabited by invertebrate-feeding brown trout (Salmo trutta), whitefish (Coregonus lavaretus), Arctic charr (Salvelinus alpinus ) and three-spined sticklebacks (Gasterosteus aculeatus ), the main predation mortality in eels is likely restricted to the very early yellow eel stages. There are reports of minks being caught in the trap and which probably also cause some mortality.

Because of the long residency in freshwater ( $>15$ years) for eels in the river Imsa, even a time series of more than 40 years is too short to allow a robust analysis of the relationship between the number of ascending recruits and the resultant number of descending silver eels. The wide silver eel age distributions, together with the stochastic environmental effect on the silvering process and annual number of descending eels, mask any potential signal from the variation in number of recruits. The annual variation in the number of recruits will be reflected in a large number of silver eel cohorts, resulting in a very smoothed signal from the variation in recruits. For example, as the age variation in female silver eels in river Imsa spans 35 years (minimum age $=5$ years, maximum age $=39$ years), a time series of 44 years (since 1975) will only include the complete number of silver eels for approximately five cohorts of recruits. In addition, as the environmental and habitat variables may have changed substantially during the 44 year period (for example temperature, Poole et al., 2018), we cannot expect a stable relationship between the numbers of ascending recruits and silver eels over the years, and attempting to split the time series into periods with relatively similar environmental conditions and fit models to these will be futile. 
In addition, we know little about the factors governing growth, mortality and strategic choices during the freshwater life phase of eels, so it will be difficult to parameterize a model adequately. For example, how should we include the effect of density in the model? Will reduced overall densities mainly affect densities in unfavorable habitats or habitats further from the sea (above the lakes), while density remain high in favorable habitats, as indicated by Boulenger et al. (2016)? Will the effect of increased density be increased mortality, due to more competition for resources or more predation from older eels, or reduced growth due to displacement to lower quality habitats? At very low densities, other effects like Allee effects, depensatory mechanisms, changing sex-ratios or life history strategies can also obscure the relationship (see references in Poole et al., 2018; Sandlund et al., 2017). One should also note that developing river-wise stock-recruitment models for European eel is not possible. The species is panmictic (Palm, Dannewitz, Prestegaard, \& Wickstrom, 2009; Als et al., 2011), with a biology that implies a weak, or no, connection between the number of silver eels leaving any watercourse for spawning in the Sargasso Sea and the number of glass eels returning to that watercourse.

In conclusion, the method of revealing annuli is one of the elements that can improve the precision and the accuracy of age estimates. Grinding and polishing the otolith seems a better method than reading the age "in toto" for older eels with a lifetime of more than one decade. However, beyond the method, there are two types of errors associated with age determination in fish: a process error related to how well the otolith reflects the complete growth record of the fish throughout its lifetime, and observation errors linked to the interpretation of these annuli (Campana, 2001). In eels, several studies have verified the correspondence between otolith structures and seasonal increments (Moriarty, 1983; Chrisnall \& Kalish 1993; Oliveira, 1996; Svedang et al., 1998), however, reading age of slow-growing eels remains a challenge. Separating false checks from real winter marks will require a proper validation of the growth increments, especially for the northern part of the distribution area where growth is slower and occurs over a shorter period. The new age distribution we determined, however, was consistent with the dynamics of elver recruitment in the river Imsa since 1975. This gives us some extra confidence in our age determination: eels have been spending on average 19 years in freshwater since the 1980s and this has only slightly increased during the 2010 (mean of 21 years). Still, the variation around these numbers is considerable, from 5 to 39 years, and this means that eels from up to 34 cohorts of recruits (elvers, small yellow eels) can be included in each year's group of descending silver eels. In this case, developing a model that links annual numbers of ascending recruits and silver eels is likely futile.

\section{Acknowledgments}

This study was funded by the Norwegian Environment Agency, the Norwegian Institute for Nature Research, and the European Inland Fisheries and Aquaculture Advisory Commission (EIFAAC) and the authors would like to acknowledge the long-term commitment to maintaining the monitoring stations. We would like to gratefully thank the technical and field staff at Imsa.

Conflict of interest

None declared.

Author contribution

All authors were involved in the conception and design of the article. Additionally, CMFD wrote the paper, analyzed and read the otoliths, analyzed and interpreted the data; OHD was involved in writing the paper, analyzed and interpreted the data. LAV analyzed the historical otolith collection and was involved in interpretation of data, drafting, and revising the manuscript. OTS, EBT, and RP were involved in interpretation of data, drafting, and revising. KB was involved in sampling the otoliths and maintenance of the time series. RHEL and SS processed and read the otoliths.

Data Availability statement

The authors agree to deposit the data in Dryad if/when the article is published. 


\section{References}

Aalto, E., Capoccioni, F., Mas, J. T., Schiavina, M., Leone, C., De Leo, G., \& Ciccotti, E. (2016). Quantifying 60 years of declining European eel (Anguilla anguilla L., 1758) fishery yields in Mediterranean coastal lagoons. ICES Journal of Marine Science, 73 (1), 101-110.

Acou, A., Lefebvre, F., Contournet, P., Poizat, G., Panfili, J., \& Crivelli, A. J. (2003). Silvering of female eels (Anguilla anguilla) in two sub-populations of the Rhone Delta. Bulletin Francais de la Peche et de la Pisciculture, $368,55-68$.

Als, T. D., Hansen, M. M., Maes, G. E., Castonguay, M., Riemann, L., Aarestrup, K., . . . Bernatchez, L. (2011). All roads lead to home: panmixia of European eel in the Sargasso Sea. Molecular Ecology, 20 (7), 1333-1346.

Aprahamian, M. (2000). The growth rate of eel in tributaries of the lower River Severn, England, and its relationship with stock size.Journal of Fish Biology, 56 (1), 223-227. doi:10.1006/jfbi.1999.1152

Arai, T., Kotake, A., \& McCarthy, T. K. (2006). Habitat use by the European eel Anguilla anguilla in Irish waters. Estuarine, Coastal and Shelf Science, 67 (4), 569-578. doi:10.1016/j.ecss.2006.01.001

Aschonitis, V., Castaldelli, G., Lanzoni, M., Rossi, R., Kennedy, C., \& Fano, E. A. (2017). Long-term records (1781-2013) of European eel (Anguilla anguilla L.) production in the Comacchio Lagoon (Italy): evaluation of local and global factors as causes of the population collapse. Aquatic Conservation: Marine and Freshwater Ecosystems, 27 (2), 502-520.

Beentjes, M. P., \& Jellyman, D. J. (2003). Enhanced growth of longfin eels, Anguilla dieffenbachii, transplanted into Lake Hawea, a high country lake in South Island, New Zealand. New Zealand Journal of Marine and Freshwater Research, 37 (1), 1-11. doi:10.1080/00288330.2003.9517141

Beentjes, M. P., \& Jellyman, D. J. (2015). Growth patterns and age validation from otolith ring deposition in New Zealand longfin eels Anguilla dieffenbachii recaptured after 10 years at large.Journal of Fish Biology, 86 (3), 924-939. doi:10.1111/jfb.12601

Bertin, L. (1956). Eels: A biological study . London: Cleaver-Hume Press.

Bornarel, V., Lambert, P., Briand, C., Antunes, C., Belpaire, C., Ciccotti, E., . . . Drouineau, H. (2018). Modelling the recruitment of European eel (Anguilla anguilla) throughout its European range.ICES Journal of Marine Science, 75 (2), 541-552.

Boulenger, C., Crivelli, A. J., Charrier, F., Roussel, J. M., Feunteun, E., \& Acou, A. (2016). Difference in factors explaining growth rate variability in European eel subpopulations: the possible role of habitat carrying capacity. Ecology of Freshwater Fish, 25 (2), 281-294.

Campana, S. (2001). Accuracy, precision and quality control in age determination, including a review of the use and abuse of age validation methods. Journal of Fish Biology, 59 (2), 197-242.

Chisnall, B. L., \& Kalish, J. M. (1993). Age validation and movement of freshwater eels (Anguilla dieffenbachii and A. australis ) in a New Zealand pastoral stream. New Zealand Journal of Marine and Freshwater Research, 27 (3), 333-338.

Davey, A. J. H., \& Jellyman, D. J. (2005). Sex determination in freshwater eels and management options for manipulation of sex.Reviews in Fish Biology and Fisheries, 15 (1-2), 37-52.

Dekker, W. (1986). Age reading of European eels using tetracycline labelled otoliths. International Council for the Exploration of the Sea C.M. 1986/M: 16; 14 pp.

Dekker, W. (2003a). On the distribution of the European eel (Anguilla anguilla) and its fisheries. Canadian Journal of Fisheries and Aquatic Sciences, 60 (7), 787-799. doi:10.1139/f03-066 
Dekker, W. (2003b). Did lack of spawners cause the collapse of the European eel, Anguilla anguilla ? Fisheries Management and Ecology, 10 (6), 365-376. doi:10.1111/j.1365-2400.2003.00352.x

Dekker, W. (2003c). Status of the European eel stock and fisheries. In K. Aida, K. Tsukamoto, \& K. Yamauchi (Eds.), Eel Biology (pp. 237-254). Tokyo: Springer-Verlag.

Dekker, W. (2004). Slipping through our hands - Population dynamics of the European eel. (PhD thesis), University of Amsterdam, 186 pp.

Dekker, W., \& Beaulaton, L. (2016). Climbing back up what slippery slope? Dynamics of the European eel stock and its management in historical perspective. ICES Journal of Marine Science, 73 (1), 5-13.

Domingos, I., Costa, J. L., \& Costa, M. J. (2006). Factors determining length distribution and abundance of the European eel, Anguilla anguilla, in the River Mondego (Portugal). Freshwater Biology, 51 (12), $2265-2281$.

Drouineau, H., Durif, C., Castonguay, M., Mateo, M., Rochard, E., Verreault, G., . . . Lambert, P. (2018). Freshwater eels: A symbol of the effects of global change. Fish and Fisheries, 19 (5), 903-930.

Durif, C., Dufour, S., \& Elie, P. (2005). The silvering process of Anguilla anguilla : a new classification from the yellow resident to the silver migrating stage. Journal of Fish Biology, 66 , 1025-1043.

Durif, C., Guibert, A., \& Elie, P. (2009). Morphological discrimination of the silvering stages of the European eel. In J. M. Casselman \& D. K. Cairns (Eds.), Eels at the edge: science, status, and conservation concerns (pp. 103-111). Bethesda, Maryland: American Fisheries Society Symposium 58.

Durif, C. M. F., Dufour, S., \& Elie, P. (2006). Impact of silvering stage, age, body size and condition on the reproductive potential of the European eel. Marine Ecology Progress Series, 327, 171-181.

Durif, C. M. F., van Ginneken, V., Dufour, S., Muller, T., \& Elie, P. (2009). Seasonal evolution and individual differences in silvering eels from different locations. In G. Van den Thillart, S. Dufour, \& J. C. Rankin (Eds.), Spawning migration of the European eel: Reproduction index, a useful tool for conservation management (Vol. 30, pp. 13-38): Springer Netherlands.

Elie, P. (1979). Contribution a l'etude des montees de civelles d'Anguilla anguilla L. (poisson teleosteen anguilliforme) dans l'estuaire de la Loire : peche, ecologie, ecophysiologie et elevage.(These de 3eme cycle), Universite de Rennes, $372 \mathrm{pp}$.

Geffroy, B., \& Bardonnet, A. (2016). Sex differentiation and sex determination in eels: consequences for management. Fish and Fisheries, 17 (2), 375-398.

Graynoth, E. (1999). Improved otolith preparation, ageing and back-calculation techniques for New Zealand freshwater eels.Fisheries Research, 42 (1-2), 137-146.

Harrison, A. J., Walker, A. M., Pinder, A. C., Briand, C., \& Aprahamian, M. W. (2014). A review of glass eel migratory behaviour, sampling techniques and abundance estimates in estuaries: implications for assessing recruitment, local production and exploitation.24 (4), 967-983.

Helfman, G. S., Facey, D. E., \& Hales, L. S. (1987). Reproductive ecology of the American eel. In M. J. Dadswell, R. J. Klauda, C. M. Moffitt, R. L. Saunders, R. A. Rulifson, \& J. E. Cooper (Eds.), Common Strategies of Anadromous and Catadromous Fishes (Vol. 1, pp. 42-56). Bethesda, Maryland: American Fisheries Society Symposium 1.

Holmgren, K., Wickstrom, H., \& Clevestam, P. (1997). Sex-related growth of European eel, Anguilla anguilla , with focus on median silver eel age. Canadian Journal of Fisheries and Aquatic Sciences, 54, 2775-2781.

Huang, Y. S., Rousseau, K., Le Belle, N., Vidal, B., Burzawa-Gerard, E., Marchelidon, J., \& Dufour, S. (1998). Insulin-like growth factor-I stimulates gonadotropin production from eel pituitary cells: a possible metabolic signal for induction of puberty. Journal of Endocrinology, 159 , 43-52. 
Huertas, M., \& Cerda, J. (2006). Stocking density at early developmental stages affects growth and sex ratio in the European eel (Anguilla anguilla ). Biological Bulletin, 211 (3), 286-296.

ICES. (2000). Report of the ICES/EIFAC Working Group on Eels(ICES CM 2000/ACFM:6). 28 pp.

ICES. (2009). Workshop on Age Reading of European and American Eel (WKAREA), 20-24 April 2009, Bordeaux, France. ICES CM 2009\ACOM: 48. 66 pp.

ICES. (2011). Report of the Workshop on Age Reading of European and American Eel (WKAREA2), 22-24 March 2011, Bordeaux, France. ICES CM 2011/ACOM:43. 35 pp.

ICES. (2016). Report of the Working Group on Eels (WGEEL), 15-22 September 2016, Cordoba, Spain. ICES CM 2016/ACOM:19. $107 \mathrm{pp}$.

ICES. (2019). Joint EIFAAC/ICES/GFCM Working Group on Eels (WGEEL). ICES Scientific Reports. 1:50. $177 \mathrm{pp}$.

Jacoby, D., \& Gollock, M. (2014). Anguilla anguilla . In: IUCN 2014. The IUCN Red List of Threatened Species.

Kettle, A. J., Vollestad, L. A., \& Wibig, J. (2011). Where once the eel and the elephant were together: decline of the European eel because of changing hydrology in southwest Europe and northwest Africa? Fish and Fisheries, 12 (4), 380-411.

Kim, N. N., Choi, Y.-U., Park, H.-S., \& Choi, C. Y. (2015). Kisspeptin regulates the somatic growth-related factors of the cinnamon clownfishAmphiprion melanopus . Comparative Biochemistry and Physiology Part A: Molecular 85 Integrative Physiology, 179 , 17-24.

Laffaille, P., Acou, A., Guillouet, J., Mounaix, B., \& Legault, A. (2006). Patterns of silver eel (Anguilla anguilla L.) sex ratio in a catchment. Ecology of Freshwater Fish, 15 (4), 583-588.

Lin, Y. J., Ložys, L., Shiao, J. C., Iizuka, Y., \& Tzeng, W. N. (2007). Growth differences between naturally recruited and stocked European eelAnguilla anguilla from different habitats in Lithuania.Journal of Fish Biology, 71 (6), 1773-1787.

Melia, P., Bevacqua, D., Crivelli, A. J., De Leo, G. A., Panfili, J., \& Gatto, M. (2006). Age and growth of Anguilla anguilla in the Camargue lagoons. Journal of Fish Biology, 68 (3), 876-890.

Moen, E., Handegard, N. O., Allken, V., Albert, O. T., Harbitz, A., \& Malde, K. (2018). Automatic interpretation of otoliths using deep learning. PLoS one, 13 (12), 14.

Moriarty, C. (1973). A technique for examining eel otoliths.Journal of Fish Biology, 5 , 183-184.

Moriarty, C. (1983). Age determination and growth rate of eels, Anguilla anguilla (L). Journal of Fish Biology, 23, 257-264.

Moriarty, C. (1986). Variations in elver abundance at European catching stations from 1938 to 1985 . Vie Et Milieu-Life and Environment, 36 (4), 233-235.

Moriarty, C. (1990). Short note on the Silver Eel Catch on the Lower River Shannon. Internationale Revue Der Gesamten Hydrobiologie, 75 , 817-818.

Moriarty, C., \& Steinmetz, B. (1979). On age determination of eel. In F. Thurow (Ed.), Eel research and management (Vol. 174, pp. 70-74): Rapports et Procès-Verbaux des Réunions Conseil International Pour L'exploration de la Mer.

Oliveira, K. (1996). Field validation of annular growth rings in the American eel, Anguilla rostrata, using tetracycline-marked otoliths. Fisheries Bulletin, 94 (1), 186-189.

Oliveira, K., McCleave, J. D., \& Wippelhauser, G. S. (2001). Regional variation and the effect of lake: river area on sex distribution of American eels. Journal of Fish Biology, 58 , 943-952. 
Palm, S., Dannewitz, J., Prestegaard, T., \& Wickström, H. (2009). Panmixia in European eel revisited: no genetic difference between maturing adults from southern and northern Europe. Heredity, 103 (1), 82-89.

Panfili, J., \& Ximénès, M. C. (1994). Évaluation de l'âge et de la croissance de l'anguille européenne (Anguilla anguilla L.) en milieu continental : méthodologies, validation, application en Méditerranée et comparaisons en Europe. Bulletin Francais de la Pêche et de la Pisciculture (335), 43-66.

Parsons, J., Vickers, K. U., \& Warden, Y. (1977). Relationship between elver recruitment and changes in sex ratio of silver eels Anguilla anguilla L. migrating from Lough Neagh, Northern Ireland. Journal of Fish Biology, 10 (3), 211-229.

Pasquier, J., Lafont, A.-G., Denis, F., Lefranc, B., Dubessy, C., Moreno-Herrera, A., . . Rousseau, K. (2018). Eel Kisspeptins: Identification, Functional Activity, and Inhibition on both Pituitary LH and GnRH Receptor Expression. Frontiers in Endocrinology, 8 .

Poole, W. R., Diserud, O. H., Thorstad, E. B., Durif, C. M., Dolan, C., Sandlund, O. T., . . Vøllestad, L. A. (2018). Long-term variation in numbers and biomass of silver eels being produced in two European river systems. ICES Journal of Marine Science .

Poole, W. R., \& Reynolds, J. D. (1996). Growth rate and age at migration of Anguilla anguilla . Journal of Fish Biology, 48 , 633-642.

Riley, W. D., Walker, A. M., Bendall, B., \& Ives, M. J. (2011). Movements of the European eel (Anguilla anguilla ) in a chalk stream. 20 (4), 628-635.

Rossi, R., Colombo, G. (1976). Some investigations on growth of silver eels of North Adriatic lagoons. Bollettino di Pesca, Piscicoltura e Idrobiologia, 31 (1-2), 283-289.

Sandlund, O. T., Diserud, O. H., Poole, R., Bergesen, K., Dillane, M., Rogan, G., . . Vøllestad, L. A. (2017). Timing and pattern of annual silver eel migration in two European watersheds are determined by similar cues. Ecology and Evolution, 7 (15), 5956-5966.

Schmidt, J., \& Regan, C. T. (1923). The breeding places of the eel.Philosophical Transactions of the Royal Society of London Series B, 211, 179-208.

Seminara, S. B., Messager, S., Chatzidaki, E. E., Thresher, R. R., Acierno, J. S., Shagoury, J. K., . . . Colledge, W. H. (2003). The GPR54 gene as a regulator of puberty. New England Journal of Medicine, 349 (17), 1614-U1618.

Silm, M., Bernotas, P., Haldna, M., Järvalt, A., \& Nõges, T. (2017). Age and growth of European eel, Anguilla anguilla (Linnaeus, 1758), in Estonian lakes. Journal of Applied Ichthyology, 33 (2), 236-241. doi:10.1111/jai.13314

Simon, J. (2007). Age, growth, and condition of European eel (Anguilla anguilla) from six lakes in the River Havel system (Germany). ICES Journal of Marine Science, 64 (7), 1414-1422. doi:10.1093/icesjms/fsm093

Simon, J. (2015). Age and growth of European eels (Anguilla anguilla) in the Elbe River system in Germany. Fisheries Research, 164, 278-285.

Svedäng, H., Wickström, H., Reizenstein, M., Holmgren, K., \& Florenius, P. (1998). Accuracy and precision in eel age estimation, using otoliths of known and unknown age. Journal of Fish Biology, 53 (2), 456-464.

Svedäng, H., Neuman, E., \& Wickström, H. (1996). Maturation patterns in female European eel: age and size at the silver eel stage. Journal of Fish Biology, 48 , 342-351.

R Core Team. (2019). R: A language and environment for statistical computing. R Foundation for Statistical Computing, Vienna, Austria. URL https://www.R-project.org/.

Tesch, F. W. (2003). The Eel (5 $5^{\text {th }}$ edition ed.). Oxford: Blackwell Publishing. 
Tzeng, W. N., Wu, H. F., \& Wickstrom, H. (1994). Scanning electron-microscopic analysis of annulus microstructure in otolith of European eel, Anguilla anguilla. Journal of Fish Biology, 45 (3), 479-492.

Vøllestad, L. A. (1985). Age determination and growth of yellow eels, Anguilla anguilla (L.), from a brackish water, Norway. Journal of Fish Biology, 26 (5), 521-525.

Vøllestad, L. A. (1992). Geographic variation in age and length at metamorphosis of maturing European eel: environmental effects and phenotypic plasticity. Journal of Animal Ecology, 61 , 41-48.

Vøllestad, L. A., \& Jonsson, B. (1986). Life-history characteristics of the European eel Anguilla anguilla in the Imsa River, Norway. Transactions of the American Fisheries Society, 115 (6), 864-871.

Vøllestad, L. A., \& Jonsson, B. (1988). A 13-year study of the population dynamics and growth of the European eel Anguilla anguilla in a Norwegian river: evidence for density-dependent mortality, and development of a model for predicting yield.Journal of Animal Ecology, 57, 983-997.

Vøllestad, L. A., Jonsson, B., Hvidsten, N. A., Naesje, T. F., Haralstad, O., \& Ruud-Hansen, J. (1986). Environmental factors regulating the seaward migration of European silver eels (Anguilla anguilla). Canadian Journal of Fisheries and Aquatic Sciences, 43 , 1909-1916.

Vøllestad, L. A., Jonsson, B., Hvidsten, N. A., \& Næsje, T. F. (1994). Experimental test of environmental factors influencing the seaward migration of European silver eels. Journal of Fish Biology, 45 , 641-651.

Vøllestad, L. A., Lecomte-Finiger, R., \& Steinmetz, B. (1988). Age determination of Anguilla anguilla (L.) and related species. EIFAC Occasional Paper, 21 , 1-28.

Vøllestad, L. A., \& Naesje, T. F. (1988). Reading otoliths of eels, Anguilla anguilla (L.), of known age from Kolderveen, The Netherlands. Aquaculture and Fisheries Management, 19 , 387-391.

Westerberg, H., \& Sjöberg, N. (2015). Overwintering dormancy behaviour of the European eel (Anguilla anguilla L.) in a large lake.Ecology of Freshwater Fish, 24 (4), 532-543.

Westerberg, H., Sjöberg, N., Lagenfelt, I., Aarestrup, K., \& Righton, D. (2014). Behaviour of stocked and naturally recruited European eels during migration. Marine Ecology Progress Series, 496 , 145-157.

Wickström, H., Westin, L., \& Clevestam, P. (1996). The biological and economic yield from a long-term stocking experiment. Ecology of Freshwater Fish, 5 , 140-147.

Zohar, Y., Munoz-Cueto, J. A., Elizur, A., \& Kah, O. (2010). Neuroendocrinology of reproduction in teleost fish. General and Comparative Endocrinology, 165 (3), 438-455.

Table 1. Summary of the otolith sample collected from silver stage European eel caught in a Wolf-trap from the river Imsa (Norway). OUI: Otolith Uncertainty Index describing the level of uncertainty when otolith was read by different readers, level 1: 1 to 3 years, level 2: 4 to 5 years, level 3: more than 5 years.

\begin{tabular}{llllll}
\hline Year & Number of fish sampled & Number aged & Number not readable & Percent not readable & Age of females $($ mean $\pm s$ \\
\hline $1980 \mathrm{~s}$ & 326 & 282 & 22 & $7 \%$ & $19 \pm 4$ \\
$1990 \mathrm{~s}$ & 336 & 304 & 12 & $4 \%$ & $19 \pm 5$ \\
$2010 \mathrm{~s}$ & 136 & 129 & 7 & $5 \%$ & $21 \pm 4^{*}$ \\
SUM & 798 & 757 & 41 & $5 \%$ & 19 \\
\hline
\end{tabular}

* Mean age of females became significantly higher only in the 2010s, $\mathrm{R}^{2}=0.03, \mathrm{~F}(2,712)=10.23, \mathrm{p}<0.0001$; t-tests 1980 s vs. $1990 \mathrm{~s}: \mathrm{p}=0.34$ and 1980 s vs. $2010 \mathrm{~s}$ : $\mathrm{p}<0.0001$.

** Mean length of females increased significantly between each decade, $\mathrm{R}^{2}=0.09, \mathrm{~F}(2,744)=35.73$; $\mathrm{p}<0.0001$ ); t-tests 1980s vs. 1990s and 1980s vs 2010s: $\mathrm{p}<0.0001$.

Figure 1. Map of the study area showing the location of the river Imsa and of the trap capturing out 
migrating silver eels (Anguilla anguilla).

Figure 2 : European eel otoliths after grinding, polishing, etching and staining. Annual rings are numbered on the pictures. Each otolith was assigned an Otolith Uncertainty Index (OUI) which corresponds to differences in readings between observers, level 1: less than 3 years, level 2: 3 to 5 years, level 3: more than 5 years. 2A: 15 years, OUI 1, body length: $67 \mathrm{~cm}$, (In toto estimate: 9 years). 2B : 18 years, OUI 2, body length: $69 \mathrm{~cm}$, (In toto estimate: 6 years). 2C: 20 years, OUI 3, body length: $67 \mathrm{~cm}$, (In toto estimate: 9 years).

Figure 3 : Differences in age estimates of eel (Anguilla anguilla) between two methods either by reading the otoliths in toto (lower end of the bar) or grinding and polishing (top end of the bar).

Figure 4: Age distribution of European eels from the river Imsa (Norway) based on otoliths read whole ("in toto" method: IT; grey bars) or grinded and polished (GP; white bars). The IT and GP age distributions were significantly different from each other (Kolmogorov-Smirnov, $\mathrm{D}=0.925, \mathrm{p}<0.0001$ ).

Figure 5 : Age distribution of European eel (undifferentiated: yellow; males: blue, females: red) caught during their downstream migration in the river Imsa between 1982 and 2016. Mean (equal to median, shown as arrows) ages of females was $19 \mathrm{y}$ in the 1980s and 1990s, and $21 \mathrm{y}$ in the 2010s.

Figure 6 : Annual number of European eels recorded in the traps in the river Imsa, 1975-2018. (A) upstream migrating recruits (mostly young of the year elvers) in the spring; the inset zooms on the period 1992-2019 and (B) downstream migrating silver eels in the fall.

Figure 7 : Length distribution of out-migrating European eel (undifferentiated: yellow; males: blue, females: red) caught during their downstream migration in the river Imsa between 1982 and 2016. Mean length of females (closed arrow) was $60 \mathrm{~cm}$ in the 1980s, $63 \mathrm{~cm}$ in the 1990s and $68 \mathrm{~cm}$ in the 2010s. Median lengths (open arrows) were 61 in the 1980s and 1990s and 69 in the 2010s.

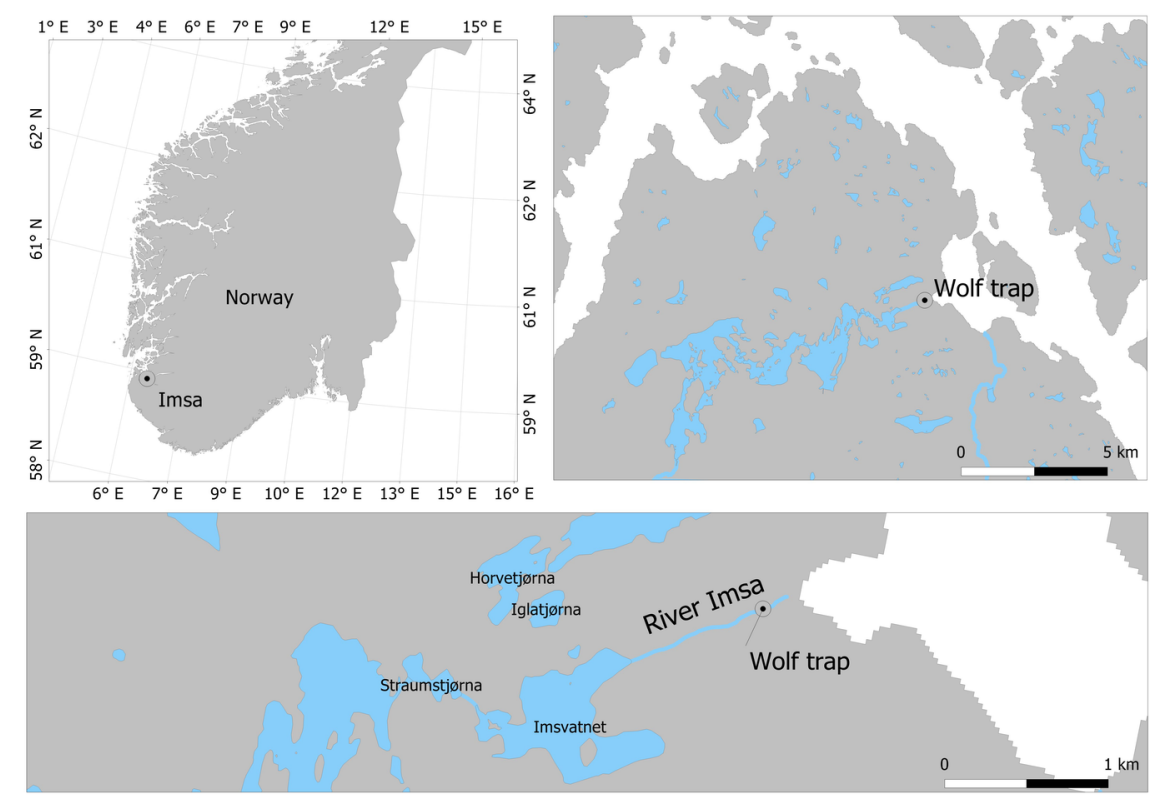



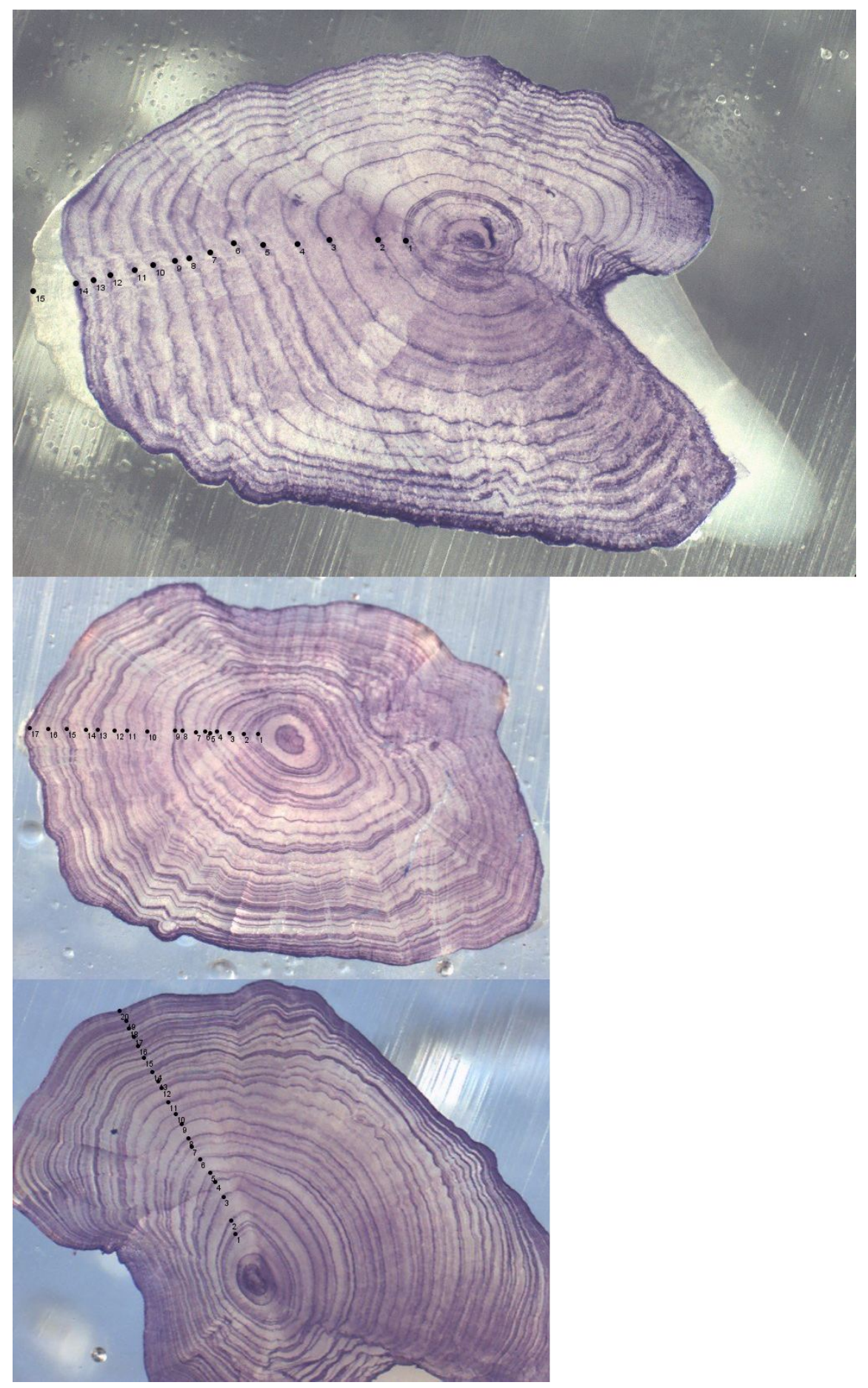

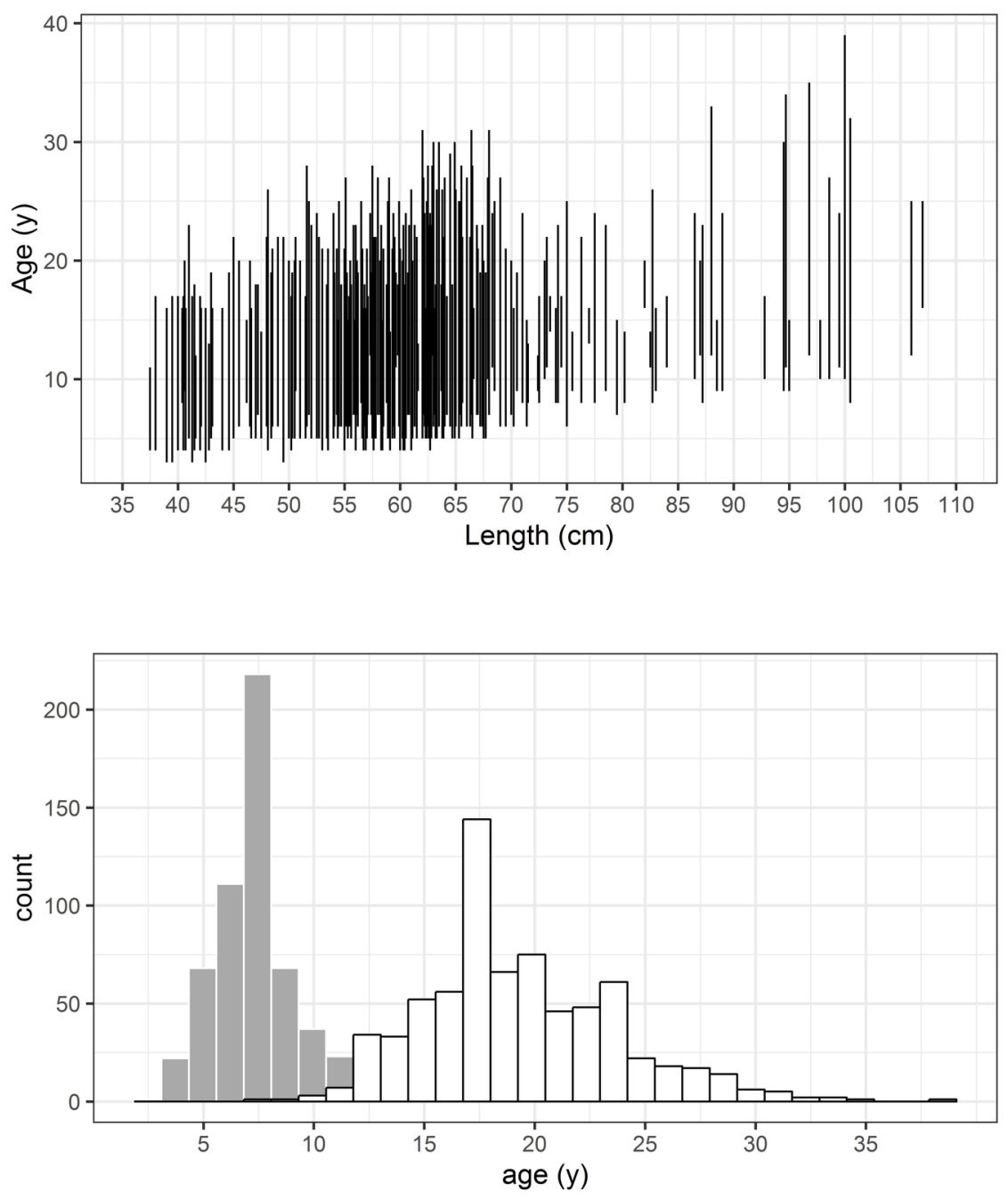

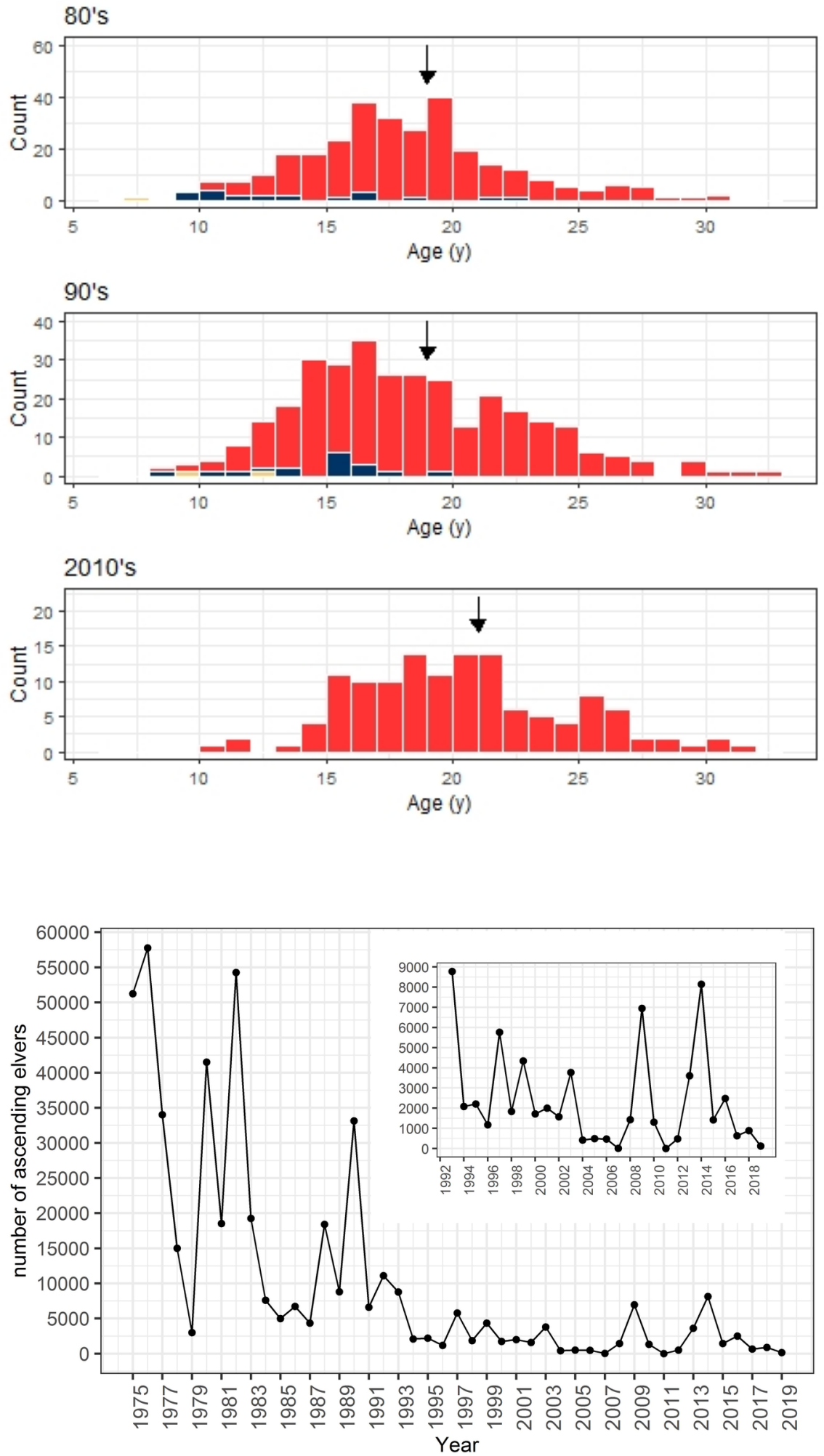

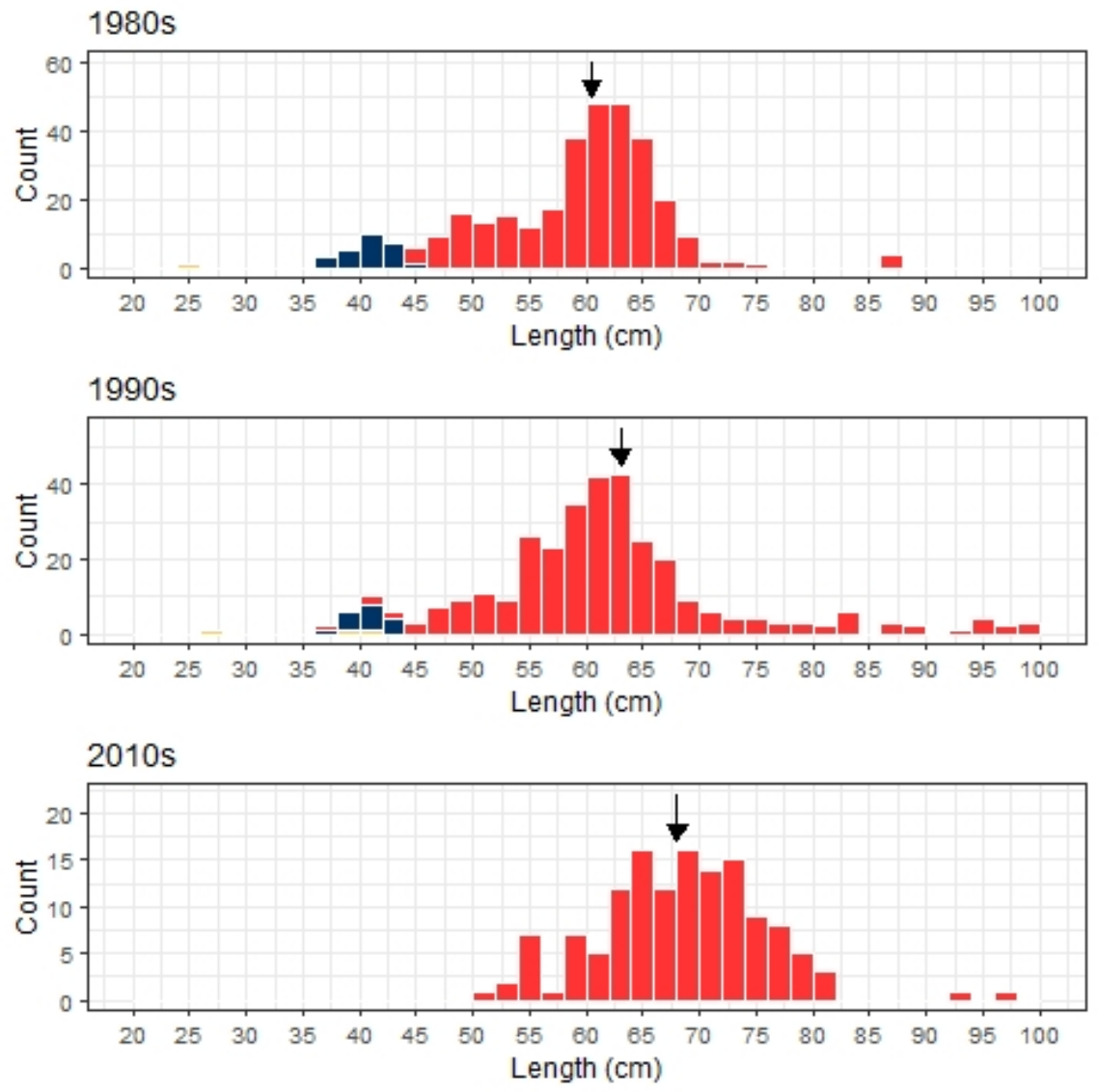